Postprint of R.M. Rivera, G. Ounoughene, C.R. Borra, K. Binnemans, T. Van Gerven (2017). Neutralisation of bauxite residue by carbon dioxide prior to acidic leaching for metal recovery. Minerals Engineering 112, 92-102.

\title{
Neutralisation of bauxite residue by carbon dioxide prior to acidic leaching for metal recovery
}

\author{
Rodolfo Marin Rivera ${ }^{\mathrm{a}}$, Ghania Ounoughene ${ }^{\mathrm{a}}$, Chenna Rao Borra ${ }^{\mathrm{a}}$, Koen Binnemans ${ }^{\mathrm{b}}$, Tom Van \\ Gerven $^{\mathrm{a}^{*}}$
}

${ }^{\text {a }}$ KU Leuven, Department of Chemical Engineering, Celestijnenlaan 200F, B-3001 Heverlee, Belgium

${ }^{\mathrm{b}}$ KU Leuven, Department of Chemistry, Celestijnenlaan 200F, B-3001 Heverlee, Belgium

*Corresponding author. Email address: tom.vangerven@kuleuven.be

\section{Highlights}

- High $\mathrm{CO}_{2}$ concentrations reduce the bauxite residue alkalinity.

- Cancrinite forms upon decomposition of sodalite with high $\mathrm{CO}_{2}$ concentration.

- High stability of aluminosilicate compounds with high sodium dissolution.

- Silica dissolution limits the recovery of metals by acidic leaching.

- The recovery of scandium is restricted by its chemical association to major elements.

\section{Abstract}

The present work considers the neutralisation of bauxite residue (red mud) with $\mathrm{CO}_{2}$ as a potential technology for reducing the acid consumption in the acidic leaching step for metal recovery. The $\mathrm{pH}$ of bauxite residue was reduced during neutralisation by the transformation of hydroxide ions to (hydrogen) carbonate ions. Neutralisation at high $\mathrm{CO}_{2}$ partial pressures and high temperatures reduces the alkalinity of the bauxite residue, but it leads to the stabilisation of silicate compounds such as cancrinite. After acidic leaching of the neutralised product with sulfuric acid, a decrease by $20 \%$ in the dissolution yield of $\mathrm{Al}, \mathrm{Fe}$, and $\mathrm{Ti}$ was observed, due to an insufficient amount of acid devoted to leaching as the transformation of calcite into bassanite and the polymerisation of silica consumed part of the acid. The recovery of Sc and La was reduced by approximately $10 \%$ in the material neutralised at high pressures and temperatures, while $\mathrm{Y}$ and $\mathrm{Nd}$ recovery was not influenced by the neutralisation. The difference in recovery yields is related to the different chemical association of minor elements with the major elements.

Key words: Neutralisation; carbon dioxide; bauxite residue; rare earths; red mud 
Postprint of R.M. Rivera, G. Ounoughene, C.R. Borra, K. Binnemans, T. Van Gerven (2017). Neutralisation of bauxite residue by carbon dioxide prior to acidic leaching for metal recovery. Minerals Engineering 112, 92-102.

\section{Introduction}

Bauxite residue (red mud) is the waste product generated during alumina production by the Bayer process and it is composed essentially of non-soluble elements such as iron and titanium minerals, undigested alumina minerals, sodium aluminium hydrosilicates, calcium minerals and significant amounts of minor and trace elements such as scandium, yttrium and lanthanides, i.e. the so-called rare earth elements (REEs) (Evans, 2016). Bauxite residue is an interesting source of REEs and especially scandium, but also of iron and titanium, while the residue after metal recovery can be used for lowcarbon building materials (Binnemans et al., 2015). Scandium concentrations in Greek bauxite residue are about $120 \mathrm{mg} / \mathrm{kg}$ (Borra et al., 2015b), but it may reach up to $260 \mathrm{mg} / \mathrm{kg}$ in some bauxite residues (Borra et al., 2016) depending on the origin and mix of bauxite minerals (raw material). The scandium concentration in bauxite residue is much higher than its average abundance in the Earth's crust (22 $\mathrm{mg} / \mathrm{kg}$ ). Therefore, the recovery of scandium from bauxite residue could be of economical interest. In fact, scandium represents more than $90 \%$ of the value of the REEs present in bauxite residue.

Several methods for recovering valuable elements from bauxite residue have been reported (Borra et al., 2016). They are mainly based on hydrometallurgical and pyrometallurgical processes, or combinations of both. Pyrometallurgical processes allow a high recovery of scandium and other REEs (Borra et al., 2015a; Tanutrov et al., 2013), but the energy consumption is high. Minor elements can be recovered by acidic leaching with $\mathrm{HCl}, \mathrm{HNO}_{3}$, or $\mathrm{H}_{2} \mathrm{SO}_{4}$ (Abhilash et al., 2014; Borra et al., 2015a; Ochsenkühn-Petropulu et al., 2002, 1996), but co-dissolution of a significant amount of iron is a serious drawback for REE recovery (Borra et al., 2015b).

The alkalinity of bauxite residue is an important issue for metal recovery by acidic leaching because part of the acid must be used for the neutralisation of the alkaline products left behind after the Bayer process. This leads to a large acid consumption and makes the recovery of metals from bauxite residue often not economical. In order to reduce the amount of acid needed for neutralisation of bauxite residue and, consequently, to develop a more sustainable process for metal recovery, alternative neutralisation routes must be considered. The use of carbonic acid $\left(\mathrm{H}_{2} \mathrm{CO}_{3}\right)$, formed during the dissolution of $\mathrm{CO}_{2}$ in water, represents an inexpensive and safe technology for bauxite residue neutralisation. The use of this 
Postprint of R.M. Rivera, G. Ounoughene, C.R. Borra, K. Binnemans, T. Van Gerven (2017). Neutralisation of bauxite residue by carbon dioxide prior to acidic leaching for metal recovery. Minerals Engineering 112, 92-102.

reagent has shown promising results in terms of $\mathrm{CO}_{2}$ sequestration and bauxite residue stabilisation for further safe disposal (Bonenfant et al., 2008; Hanahan et al., 2004; Lutpi and Zhu, 2010; Rai et al., 2013; Yadav et al., 2010). However, the use of $\mathrm{CO}_{2}$ as a neutralisation reagent for bauxite residue as part of a flow sheet to reduce acid consumption during the metal recovery by acidic leaching has not been studied yet.

The objective of this paper is to evaluate the recovery of valuable metals after the reduction of bauxite residue's alkalinity by transformation of hydroxides into soluble carbonate compounds during the neutralisation by $\mathrm{CO}_{2}$, at different conditions. Neutralisation with a mineral acid at similar conditions is compared to the neutralisation with $\mathrm{CO}_{2}$. The neutralised solid fraction is leached with sulfuric acid at different concentrations to dissolve major and minor elements and the metal extraction efficiency is correlated with the neutralisation conditions. The acid consumption is also evaluated.

\section{Material and methods}

The bauxite residue studied in this paper was kindly provided by Aluminium of Greece (Agios Nikolaos, Greece). It originates from a mixture of karst and lateritic bauxites. It was received from the alumina refinery after dewatering by filter presses and room temperature drying. Upon arrival in the lab, the sample was further dried at $105^{\circ} \mathrm{C}$ for $24 \mathrm{~h}$. Chemical analysis of the major elements in bauxite residue was performed using wavelength dispersive X-ray fluorescence spectroscopy (WDXRF, Panalytical PW2400). Chemical analysis of minor elements was performed after complete dissolution of the bauxite residue by alkali fusion and acid digestion in $3 \% \mathrm{HNO}_{3}$ solution, followed by Inductively Coupled Plasma Mass Spectrometry (ICP-MS, Thermo Electron X Series) analysis. The mineralogy of the samples was studied by X-ray powder diffraction (XRD, Bruker D2 Phaser). The obtained data were evaluated with EVA V.3.1 (Bruker AXS) and quantified with Topas-Academic V.5, using the Rietveld method. Thermo-gravimetric analysis (TGA, Netzsch STA 409) were carried out in a nitrogen atmosphere from room temperature to $1000^{\circ} \mathrm{C}$ at a heating rate of $10^{\circ} \mathrm{C} / \mathrm{min}$ in order to identify phase transformation and thermal decompositions in the bauxite residue. 
Postprint of R.M. Rivera, G. Ounoughene, C.R. Borra, K. Binnemans, T. Van Gerven (2017). Neutralisation of bauxite residue by carbon dioxide prior to acidic leaching for metal recovery. Minerals Engineering 112, 92-102.

Neutralisation at ambient conditions of bauxite residue with $\mathrm{CO}_{2}$ gas was performed in a three-neck flask reactor $(400 \mathrm{~mL})$ with continuous agitation (magnetic stirrer at $478 \mathrm{rpm})$. Within the reactor, solid particles were mixed with water at a liquid-to-solid ratio, $L / S$, of 5:1. $\mathrm{CO}_{2}$ gas $(99.9925 \%$, Air Liquide) was introduced continuously at defined flow rate, which was controlled with a flow meter. A diffuser (PTFE, pore size of $10 \mu \mathrm{m}$ ) was used to spread out the gas into the formed slurry.

High-pressure neutralisation experiments were carried out in a titanium autoclave (Parr Company, series 4560) varying the partial pressure of $\mathrm{CO}_{2}$ and temperature. Bauxite residue and Milli-Q water were mixed during a period of 5 minutes in a beaker at a $L / S$ of 5:1 at ambient conditions. The slurry was poured into the titanium vessel $(200 \mathrm{~mL})$ and mounted in the autoclave. Nitrogen gas at a pressure of 5 bar was used to remove the excess of oxygen gas inside the reactor, so that potential oxidative reactions could be prevented.

Neutralisation of bauxite residue with $\mathrm{HCl}$ (37\%, Fisher Scientific) was performed with a $L / S$ ratio of 5:1 in sealed polyethylene bottles by constant agitation using a laboratory shaker (Gerhardt Laboshake) at $200 \mathrm{rpm}$ and $25^{\circ} \mathrm{C}$. The slurries after neutralisation were filtered using filter paper (pore size 0.45 $\mu \mathrm{m})$ and diluted with $2 \% \mathrm{HNO}_{3}$ for Inductively Coupled Plasma Optical Emission Spectroscopy (ICPOES, PerkinElmer Optima 8300) analysis for major elements (e.g., Al, Fe, Ca, Na, Si, Ti).

Leaching of the non-neutralised and the neutralised bauxite residue was carried out with sulfuric acid (95-97\%, Sigma-Aldrich) with a $L / S$ ratio of $10: 1$. The experiments were performed in the same laboratory shaker at $200 \mathrm{rpm}$ and $25^{\circ} \mathrm{C}$. The leach solution (pregnant leach solution, PLS) was filtered using a syringe filter (pore size of $0.45 \mu \mathrm{m}$ ) and diluted with $2 \% \mathrm{HNO}_{3}$ for ICP-OES analysis for major and minor (e.g., Sc, Y, La, Nd) elements. Lutetium was used as internal standard during the analysis. A synthetic solution with a pre-defined concentration was used as reference. 
Postprint of R.M. Rivera, G. Ounoughene, C.R. Borra, K. Binnemans, T. Van Gerven (2017). Neutralisation of bauxite residue by carbon dioxide prior to acidic leaching for metal recovery. Minerals Engineering 112, 92-102.

109

110

111

112

117 Table 1: Major chemical components in the bauxite residue.

\begin{tabular}{cc}
\hline Compound & wt\% \\
\hline $\mathrm{Fe}_{2} \mathrm{O}_{3}$ & 46.7 \\
$\mathrm{Al}_{2} \mathrm{O}_{3}$ & 18.1 \\
$\mathrm{CaO}$ & 8.5 \\
$\mathrm{SiO}_{2}$ & 7.3 \\
$\mathrm{TiO}_{2}$ & 5.8 \\
$\mathrm{Na}_{2} \mathrm{O}$ & 2.8 \\
Loss on ignition & 8.5 \\
\hline
\end{tabular}

118

\section{Results and discussion}

\subsection{Characterisation of the bauxite residue} residue are relatively high.

\begin{tabular}{cc}
\hline Element & $\begin{array}{c}\text { Concentration, } \\
\text { g/tonne }\end{array}$ \\
\hline $\mathrm{Sc}$ & $121 \pm 10$ \\
$\mathrm{Y}$ & $76 \pm 10$ \\
$\mathrm{La}$ & $114 \pm 15$ \\
$\mathrm{Nd}$ & $99 \pm 7$ \\
\hline
\end{tabular}

The concentrations of major elements in the form of oxides in our Greek bauxite residue sample are given in Table 1. Iron(III) oxide is the major oxide in the bauxite residue followed by alumina, calcium oxide, silica, titanium oxide and sodium oxide. In Table 2, the concentrations of selected REEs are shown. The concentrations of Sc, Y, La and Nd are shown because their concentrations in bauxite

\section{Table 2: Selected rare-earth elements composition of the bauxite residue sample (Borra et al., 2015b).}

Mineralogical analysis allowed the identification of several mineral phases, based on iron (hematite, goethite), aluminium (gibbsite, diaspore, bayerite), calcium (calcite, calcium silicates and calcium alumino-silicates), sodium (sodalite, cancrinite) and titanium (rutile). Approximately $95 \%$ of the mineral phases were quantified using the Rietveld method (see Table S1 and S2). Table 3 describes the normalised (to $100 \%$ total) mineralogical composition of the bauxite residue sample. The quantification of mineral phases was analysed by taking into account the chemical composition of major elements obtained by XRF analysis (Table 1) with an estimated deviation error of approximately $10 \%$. 
Postprint of R.M. Rivera, G. Ounoughene, C.R. Borra, K. Binnemans, T. Van Gerven (2017). Neutralisation of bauxite residue by carbon dioxide prior to acidic leaching for metal recovery. Minerals Engineering 112, 92-102.

Table 3: Normalised mineralogical composition of the bauxite residue sample.

\begin{tabular}{llc}
\hline Phase & $\mathrm{Chemical}_{\text {formula }}$ & wt\% \\
\hline Hematite & $\mathrm{Fe}_{2} \mathrm{O}_{3}$ & 36 \\
Dicalcium-silicate $\left(\mathrm{C}_{2} \mathrm{~S}\right)$ & $\mathrm{Ca}_{2} \mathrm{SiO}_{4}$ & 12 \\
Gibbsite & $\mathrm{Al}(\mathrm{OH})_{3}$ & 8 \\
Hydrogrossular & $\mathrm{Ca}_{3} \mathrm{Al}_{2}\left(\mathrm{SiO}_{4}\right)_{1.53}(\mathrm{OH})_{5.88}$ & 7 \\
Diaspore & $\mathrm{AlO}(\mathrm{OH})$ & 7 \\
Grossular & $\mathrm{Ca}_{3} \mathrm{Al}_{2}\left(\mathrm{SiO}_{4}\right)_{3}$ & 5 \\
Tricalcium-silicate $\left(\mathrm{C}_{3} \mathrm{~S}\right)$ & $\mathrm{Ca}_{3} \mathrm{SiO}_{5}$ & 5 \\
Goethite & $\mathrm{FeO}(\mathrm{OH})$ & 5 \\
Calcite & $\mathrm{CaCO}_{3}$ & 4 \\
Bayerite & $\alpha-\mathrm{Al}_{(}\left(\mathrm{OH}_{3}\right.$ & 4 \\
Sodalite & $\mathrm{Na}_{6}\left(\mathrm{Al}_{6} \mathrm{Si}_{6} \mathrm{O}_{24}\right) \cdot x \mathrm{NaOH} \cdot(8-2 x) \mathrm{H}_{2} \mathrm{O}$ & 3 \\
Calcium phyllo-dodeca- \\
alumotetrasilicate & $\mathrm{Al}_{12} \mathrm{CaO}_{27} \mathrm{Si}_{4}$ & 2 \\
Rutile & $\mathrm{TiO}_{2}$ & 2 \\
Cancrinite & $\mathrm{Na}_{6} \mathrm{Ca}_{2} \mathrm{Al}_{6} \mathrm{Si}_{6} \mathrm{O}_{24}\left(\mathrm{CO}_{3}\right)_{2} \cdot 2 \mathrm{H}_{2} \mathrm{O}$ & 1 \\
\hline
\end{tabular}

\subsection{Neutralisation - leaching}

132 The effect of neutralisation of bauxite residue with $\mathrm{CO}_{2}$ gas on the acid consumption and the recovery

133 of selected REEs from bauxite residue was evaluated in two consecutive experimental processes

134 according to the diagram presented in Figure 1: (1) neutralisation of bauxite residue slurry with $\mathrm{CO}_{2}$ gas, and (2) acidic leaching of the (non-) neutralised bauxite residue. 
Postprint of R.M. Rivera, G. Ounoughene, C.R. Borra, K. Binnemans, T. Van Gerven (2017). Neutralisation of bauxite residue by carbon dioxide prior to acidic leaching for metal recovery. Minerals Engineering 112, 92-102.

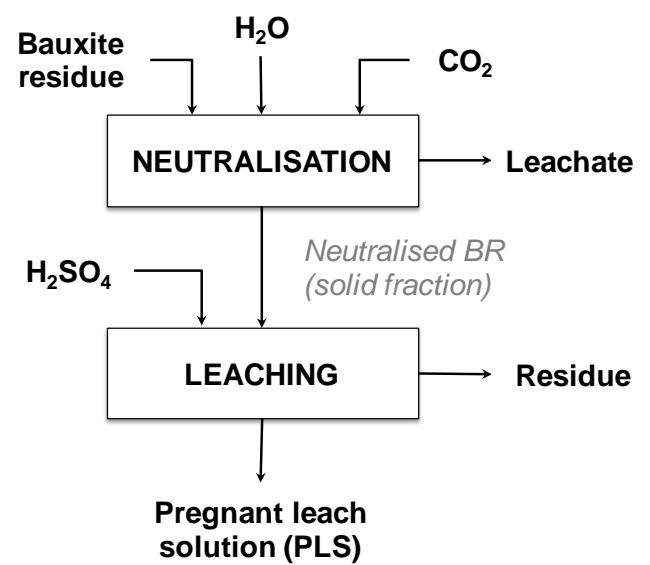

Figure 1: Flow sheet for neutralisation of bauxite residue, followed by metal recovery from neutralised bauxite residue by leaching with sulfuric acid.

\subsection{Neutralisation of bauxite residue with water}

Bauxite residue was washed with water to study the potential change in $\mathrm{pH}$ of bauxite residue with the removal of sodium hydroxide. The experiment was conducted in duplicate at a $L / S$ ratio of 5:1. After a washing period of $24 \mathrm{~h}$, the $\mathrm{pH}$ remained stable at 10.7, which corresponded to the original $\mathrm{pH}$ of our bauxite residue sample. This is due to the buffering activity of alkaline solids that are present in the sample (Gräfe et al., 2011). It was observed that about $8 \mathrm{wt} \%$ of the total sodium was removed from the solid matrix after washing, due to its chemical association to alumina-silicate compounds, such as sodalite and cancrinite (see Table 3). It has been reported that the solubility of alumino-silicates decreases with increasing presence of sodium carbonate (Zheng et al., 1998, 1997). However, there is a knowledge gap related to the solubility of silicate compounds remaining after the final separation stages of the Bayer process, so that it is difficult to assess the conditions at which such compounds become more or less soluble.

\subsection{Neutralisation of bauxite residue with different gas flow rates}

The studies were carried out in a reactor of $400 \mathrm{~mL}$ with gas flow rates of $0.008,0.02,0.1$ and 0.25 $\mathrm{L} / \mathrm{min}$. The initial $\mathrm{pH}$ of the slurry, i.e. 10.7, decreased over a period of 2 hours with continuous gas blown through the reactor to an average value of 6.8 for all investigated flow rates (Figure 2). The most 
Postprint of R.M. Rivera, G. Ounoughene, C.R. Borra, K. Binnemans, T. Van Gerven (2017). Neutralisation of bauxite residue by carbon dioxide prior to acidic leaching for metal recovery. Minerals Engineering 112, 92-102. remarkable changes were observed in the neutralisation rate, which was evaluated by considering the

$$
\begin{gathered}
\mathrm{CO}_{2(\mathrm{~g})} \stackrel{\leftrightarrows}{ } \mathrm{CO}_{2(\mathrm{aq})} \\
{\left[\mathrm{CO}_{2(\mathrm{aq})}\right]=K_{\mathrm{CO} 2}\left(P_{\mathrm{CO} 2(\mathrm{~g})}\right)}
\end{gathered}
$$


Postprint of R.M. Rivera, G. Ounoughene, C.R. Borra, K. Binnemans, T. Van Gerven (2017). Neutralisation of bauxite residue by carbon dioxide prior to acidic leaching for metal recovery. Minerals Engineering 112, 92-102.

where $K_{\mathrm{CO} 2}$ represents Henry's law constant of $\mathrm{CO}_{2}$, equal to $3.38 \times 10^{-2}$ (mol/L/atm) (Reddy and Balasubramanian, 2014), and $P_{\mathrm{CO} 2(\mathrm{~g})}$ is the partial pressure (in atm) of $\mathrm{CO}_{2}$ gas in the atmosphere. At ambient conditions, $P_{\mathrm{CO} 2}$ depends on the number of $\mathrm{CO}_{2}$ molecules dissolved in water and, consequently, on the magnitude of the gas flow rate. Therefore, a high gas flow rate leads to a large dissolution of $\mathrm{CO}_{2}$ molecules in water and, thus, to an increase in $P_{\mathrm{CO} 2}$. The interaction between $\mathrm{CO}_{2}$ and water leads to the formation of carbonic acid $\mathrm{H}_{2} \mathrm{CO}_{3}$, which is a weak acid (equation 3). Dissolution of $\mathrm{H}_{2} \mathrm{CO}_{3}$ in water involves two dissociations. The first dissociation is related to the formation of the hydrogen carbonate (bicarbonate) ion, $\mathrm{HCO}_{3}^{-}$(equation 4), while the second dissociation involves the dissociation of the hydrogen carbonate ion into the carbonate ion, $\mathrm{CO}_{3}{ }^{2-}$ (equation 5). Both chemical reactions involve the release of $\mathrm{H}^{+}$ions into the solution, leading to a decrease in $\mathrm{pH}$ until equilibrium is reached. For instance, the final $\mathrm{pH}$ attained after 2 hours of neutralisation with $\mathrm{CO}_{2}$ gas corresponds to the $\mathrm{pH}$ associated to the first chemical decomposition of the carbonic acid, i.e. the formation of the hydrogen carbonate ion, when the gas was introduced continuously into the reactor.

$$
\begin{array}{rlr}
\mathrm{CO}_{2(\mathrm{aq})}+\mathrm{H}_{2} \mathrm{O} \leftrightarrows \mathrm{H}_{2} \mathrm{CO}_{3} & \\
\mathrm{H}_{2} \mathrm{CO}_{3} \leftrightarrows \mathrm{HCO}_{3}{ }^{-}+\mathrm{H}^{+} & & \\
\mathrm{HCO}_{3}{ }^{-} \leftrightarrows \mathrm{CO}_{3}{ }^{2-}+\mathrm{H}^{+} & p K_{\mathrm{a} 2}=6.35 \text { at } 25^{\circ} \mathrm{C} \\
& 5.2 \text { at } 25^{\circ} \mathrm{C}
\end{array}
$$

The $\mathrm{pH}$ of the neutralised sample was measured for 2 days after the end of the experiment (no $\mathrm{CO}_{2}$ was blown inside the reactor, and the slurry was left at ambient conditions and in steady state). An increase of the $\mathrm{pH}$ to an average value of 9.3 was observed (Figure 2), due to the presence of unreacted sodalite and hydroxide compounds that buffer the bauxite residue (Cooling et al., 2002; Khaitan et al., 2009b). This rebound of $\mathrm{pH}$ has been already reported by other researchers (Han et al., 2017; Kirwan et al., 2013; Rai et al., 2012; Sahu et al., 2010). It is evident that in the absence of continuous $\mathrm{CO}_{2}$ gas injection, the concentration of $\mathrm{HCO}_{3}{ }^{-} / \mathrm{CO}_{3}{ }^{2-}$ is limited and, consequently, alkaline anions in solution such as $\mathrm{Al}(\mathrm{OH})_{4}^{-}\left(\mathrm{pK}_{\mathrm{a}} \sim 10.2\right)$ and $\mathrm{OH}^{-}\left(\mathrm{pK}_{\mathrm{w}}=14\right)($ Gräfe et al., 2011) start buffering the $\mathrm{pH}$ of the slurry (Sahu et al., 2010) . 
Postprint of R.M. Rivera, G. Ounoughene, C.R. Borra, K. Binnemans, T. Van Gerven (2017). Neutralisation of bauxite residue by carbon dioxide prior to acidic leaching for metal recovery. Minerals Engineering 112, 92-102.

$$
\begin{aligned}
\mathrm{Ca}^{2+}+\mathrm{HCO}_{3}^{-} & \leftrightarrows \mathrm{CaCO}_{3(\mathrm{~s})}+\mathrm{H}^{+} \\
\mathrm{Ca}^{2+}+\mathrm{HCO}_{3}^{-} & \leftrightarrows \mathrm{CaHCO}_{3(\mathrm{aq})}
\end{aligned}
$$


Postprint of R.M. Rivera, G. Ounoughene, C.R. Borra, K. Binnemans, T. Van Gerven (2017). Neutralisation of bauxite residue by carbon dioxide prior to acidic leaching for metal recovery. Minerals Engineering 112, 92-102.

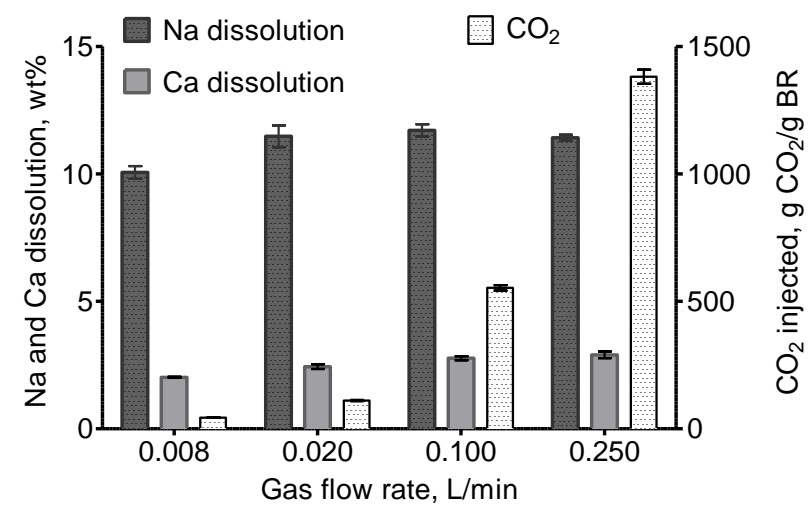

Figure 3: Effect of gas flow rate on the dissolution of $\mathrm{Na}$ and $\mathrm{Ca}$ from the neutralised bauxite residue and $\mathrm{CO}_{2}$ injected (BR: bauxite residue, $T: 25^{\circ} \mathrm{C}, L / S: 5, t: 2 \mathrm{~h}$ ).

Neutralisation with a strong acid, such as $\mathrm{HCl}$, may cause a substantial reduction of the material's alkalinity, depending on the acid concentration (Khaitan et al., 2009a). The addition of acid in a pH range between 6 and 7 involves the partial decomposition of silica compounds, but also of calcite. Hence, an increase of $\mathrm{Na}$ and $\mathrm{Ca}$ dissolution is expected. Figure 4 describes the effect of acid concentration on the $\mathrm{pH}$ and on $\mathrm{Na}$ and $\mathrm{Ca}$ dissolution in the bauxite residue sample. A higher dissolution of $\mathrm{Na}$ and $\mathrm{Ca}$ in comparison to neutralisation with carbonic acid (formed during the dissolution of $\mathrm{CO}_{2}$ in water) was observed. However, it is necessary to highlight the significant difference in the corresponding cost associated to the use of mineral acids or $\mathrm{CO}_{2}$ for neutralisation. The price of the acid may reach a value of up to $200 \mathrm{USD} /$ tonne (www.sunsirs.com), while the use of

$233 \mathrm{CO}_{2}$ is a less expensive reagent, because it can be obtained from the gas emissions generated during the 234 alumina production (Bayer process). In addition, the use of $\mathrm{CO}_{2}$ for neutralisation may help to reduce the greenhouse effect due to its removal from the industrial flue gases. 
Postprint of R.M. Rivera, G. Ounoughene, C.R. Borra, K. Binnemans, T. Van Gerven (2017). Neutralisation of bauxite residue by carbon dioxide prior to acidic leaching for metal recovery. Minerals Engineering 112, 92-102.

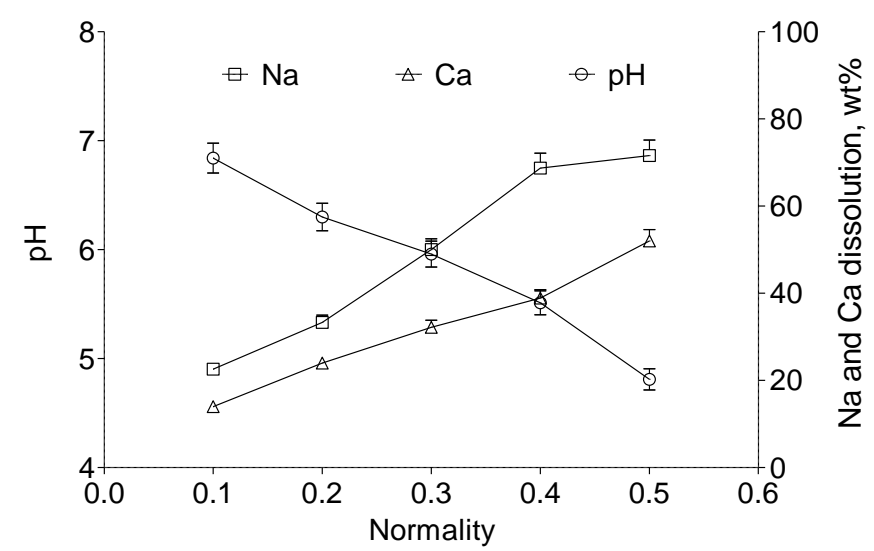

Figure 4: Neutralisation of bauxite residue with mineral acid and $\mathrm{Na}$ and $\mathrm{Ca}$ dissolution at different acid concentration ( $\left.\mathrm{HCl}, T: 25^{\circ} \mathrm{C}, L / S: 5, t: 24 \mathrm{~h}\right)$.

\subsection{High pressure neutralisation}

The effect of $\mathrm{CO}_{2}$ partial pressure on the dissolution of sodium and calcium and on $\mathrm{pH}$, during neutralisation of the bauxite residue, is shown in Figure 5. The increase of $\mathrm{CO}_{2}$ partial pressure leads to an increase of sodium dissolution, and to a very small increase in the dissolution of calcium due to the relatively high solubility of $\mathrm{CO}_{2(\mathrm{~g})}$ in water $\left(0.14 \mathrm{~g} \mathrm{CO}_{2} / 100 \mathrm{~g}\right.$ water at $\left.25{ }^{\circ} \mathrm{C}\right)$. The $\mathrm{pH}$ of the slurry remained around 9.2. Figure 6 describes the effect of temperature during neutralisation of bauxite residue with 30 bar of $\mathrm{CO}_{2}$ partial pressure. A significant increase in sodium dissolution was observed when the temperature increased. The concentration of calcium in solution decreased due to the precipitation of calcite when the temperature was increased. The solubility of $\mathrm{CO}_{2}$ in water decreases with an increase in temperature at constant partial pressure of the $\mathrm{CO}_{2}$ in the gas phase above the bulk liquid, but it does increase when its partial pressure above the solution increases and, consequently, the concentration of $\mathrm{HCO}_{3}-\mathrm{CO}_{3}{ }^{2-}$ also increases. This relationship can be summarised by combining Le Châtelier's principle, i.e. the shift of the chemical equilibrium in the direction at which the pressure is released, and Henry's law, i.e. the increase in concentration of the gas in the liquid when the partial pressure increases (see equation 2). The effect of temperature on the solubility reduction of $\mathrm{CO}_{2}$ becomes less significant when the $\mathrm{CO}_{2}$ partial pressure is increased (Santos et al., 2013). The decrease 
Postprint of R.M. Rivera, G. Ounoughene, C.R. Borra, K. Binnemans, T. Van Gerven (2017). Neutralisation of bauxite residue by carbon dioxide prior to acidic leaching for metal recovery. Minerals Engineering 112, 92-102.

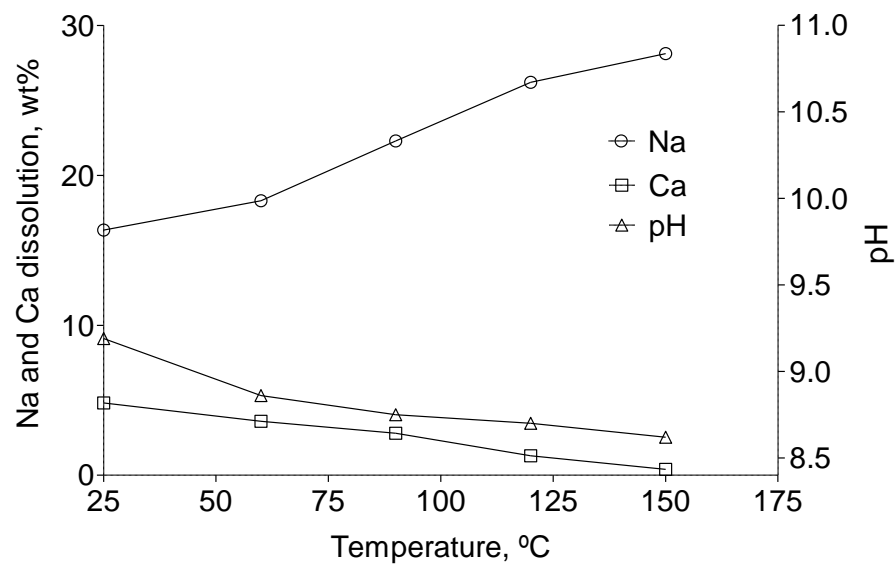

Figure 6: Dissolution of $\mathrm{Na}$ and Ca during neutralisation at different temperatures $\left(P_{\mathrm{CO} 2}: 30 \mathrm{bar}, L / S: 5, t: 2 \mathrm{~h}\right)$

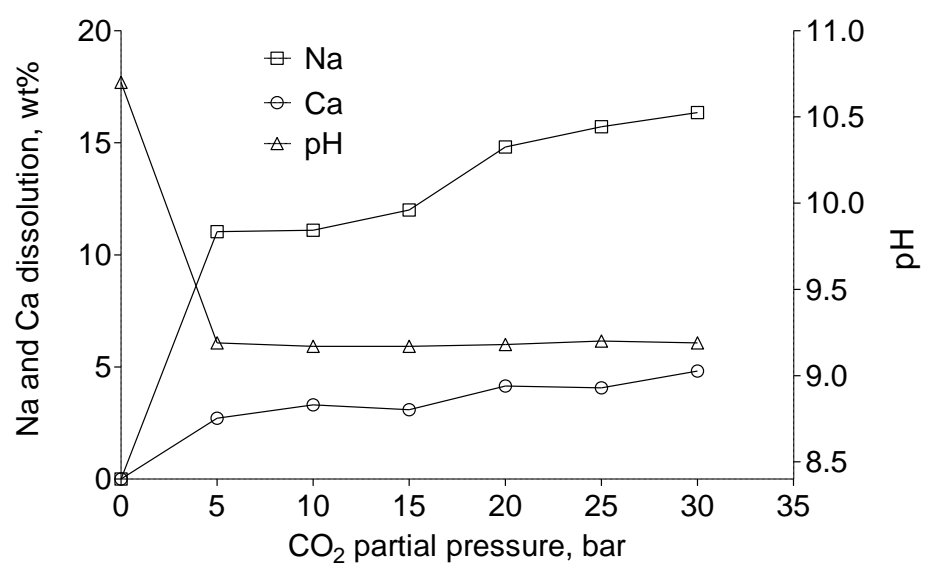

Figure 5: Dissolution of $\mathrm{Na}$ and $\mathrm{Ca}$ during neutralisation at different $\mathrm{CO}_{2}$ partial pressures $\left(T: 25^{\circ} \mathrm{C}, L / S: 5, t: 2\right.$ h).

The identification of phase transformation and thermal decomposition in the non-neutralised and neutralised bauxite residue was confirmed by thermo-gravimetric analysis (Figure 7). The mass loss between 270 and $600{ }^{\circ} \mathrm{C}$ is due to the loss of chemically bound water, mainly from goethite (between 292 and $355^{\circ} \mathrm{C}$ ) (Rizov, 2012), gibbsite (between 300 and $400{ }^{\circ} \mathrm{C}$ ) and diaspore (between 400 and 600 $\left.{ }^{\circ} \mathrm{C}\right)$ (Agatzini-Leonardou et al., 2008). The first endothermic peak on the differential thermogravimetry (DTG) curve describes the dehydration of gibbsite to form both boehmite and $\alpha$-alumina, i.e. between 270 and $320^{\circ} \mathrm{C}$ (Kloprogge et al., 2002). The dehydration peak of gibbsite is more intense in the highly 
Postprint of R.M. Rivera, G. Ounoughene, C.R. Borra, K. Binnemans, T. Van Gerven (2017). Neutralisation of bauxite residue by carbon dioxide prior to acidic leaching for metal recovery. Minerals Engineering 112, 92-102.

neutralised sample than in the non-neutralised one, presumably due to its chemical transformation into grossular when $\mathrm{Ca}$ and $\mathrm{Na}$ were dissolved (Whittington and Cardile, 1996), i.e. during the carbonation period. The second endothermic reaction is observed at $510{ }^{\circ} \mathrm{C}$ and it is attributed to the decomposition of diaspore (Atasoy, 2005). The mass loss between 600 and $800^{\circ} \mathrm{C}$ was much more pronounced in the neutralised sample compared to the non-neutralised bauxite residue, due to the release of relatively more $\mathrm{CO}_{2}$ from the neutralised sample as a consequence of the decomposition of $\mathrm{CaCO}_{3}$ (AgatziniLeonardou et al., 2008) formed during neutralisation.

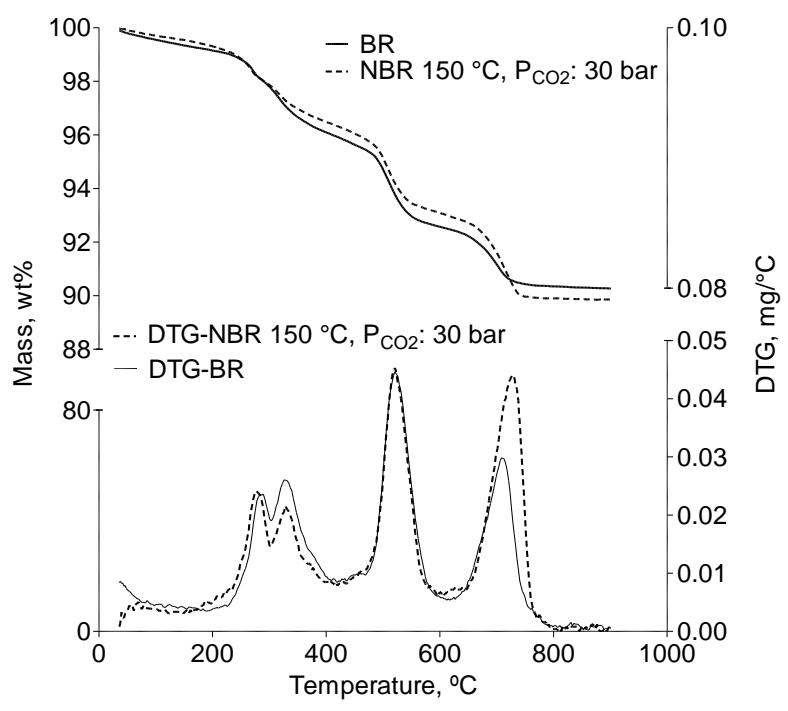

Figure 7: TGA (left y-axis) and DTG (right y-axis) curves of the non-neutralised (BR) and neutralised (NBR) bauxite residue sample.

Figure 8 describes the change in composition of selected mineralogical phases. The composition of calcite, $\mathrm{C}_{2} \mathrm{~S}$, cancrinite and sodalite are shown as their concentration significantly changed during neutralisation (BR $=$ nonneutralised bauxite residue, $\mathrm{NBR}=$ neutralised bauxite residue at ambient conditions $\left(q_{\mathrm{CO} 2}: 0.25 \mathrm{~L} / \mathrm{min}, T: 25^{\circ} \mathrm{C}, L / S: 5\right)$, $\mathrm{NBR}=$ high-pressure neutralised bauxite residue $\left(P_{\mathrm{CO} 2}: 30\right.$ bar, $\left.T: 25^{\circ} \mathrm{C}, L / S: 5\right)$, HPT NBR = high-pressure and high-temperature neutralised bauxite residue (PCO2: 30 bar, $\left.\mathrm{T}: 150{ }^{\circ} \mathrm{C}, \mathrm{L} / \mathrm{S}: 5\right) \ldots$. 
Postprint of R.M. Rivera, G. Ounoughene, C.R. Borra, K. Binnemans, T. Van Gerven (2017). Neutralisation of bauxite residue by carbon dioxide prior to acidic leaching for metal recovery. Minerals Engineering 112, 92-102.

Table S2). The calcite content increases when the $\mathrm{CO}_{2}$ partial pressure and temperature increased. Nonetheless, the amount of $\mathrm{CO}_{2}$ consumed during the formation of calcite at high pressure and temperature registered at only $1 \mathrm{wt} \%$. Formation of calcite may be explained by the decomposition of $\mathrm{C}_{2} \mathrm{~S}$, and also by the partial decomposition of cancrinite (Kirwan et al., 2013). However, strong neutralisation conditions (temperature and pressure) lead to an increase in the concentration of cancrinite as a consequence of sodalite decomposition (Barnes et al., 1999). Silicate compounds such as cancrinite and grossular became more stable in the neutralised samples rather than in the nonneutralised bauxite residue, due to the decrease of $\mathrm{SiO}_{2}$ solubility with the increase of $\mathrm{Na}_{2} \mathrm{CO}_{3}$ concentration in the slurry (Zheng et al., 1998).

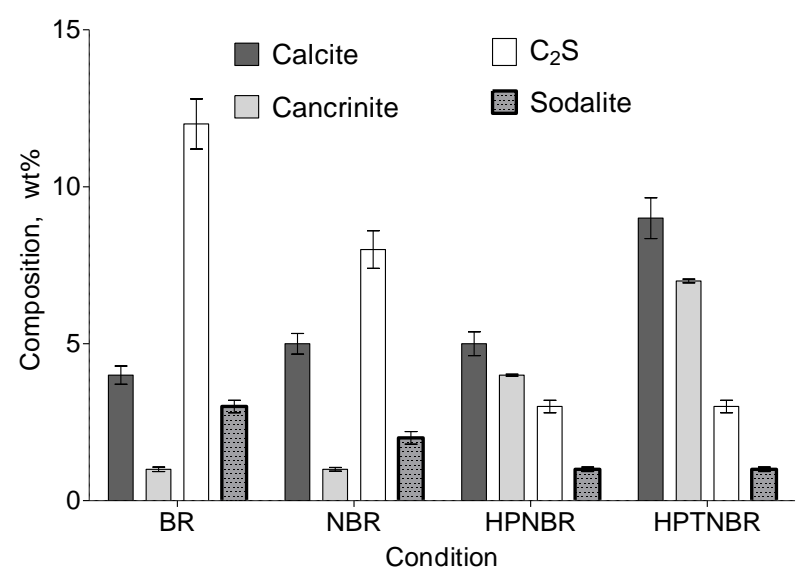

Figure 8: Change of composition in selected mineralogical phases. BR: non-neutralised bauxite residue, NBR: neutralised bauxite residue at ambient conditions ( $\left.q_{\mathrm{CO} 2}: 0.25 \mathrm{~L} / \mathrm{min}, T: 25^{\circ} \mathrm{C}, L / S: 5\right)$, HPNBR: high-pressure neutralised bauxite residue $\left(P_{\mathrm{CO} 2}: 30 \mathrm{bar}, T: 25^{\circ} \mathrm{C}, L / S: 5\right)$, HPTNBR: high-pressure and high-temperature neutralised bauxite residue $\left(P_{\mathrm{CO} 2}: 30\right.$ bar , $\left.T: 150^{\circ} \mathrm{C}, L / S: 5\right)$.

\subsection{Leaching of neutralised bauxite residue}

Figure 9 shows the effect of acid concentration on the $\mathrm{pH}$ of the solution for both neutralised and nonneutralised bauxite residue. Evidently, the $\mathrm{pH}$ decreases and the acid consumption increases when the acid concentration is increased. However, neutralised samples achieved lower $\mathrm{pH}$ values compared to the non-neutralised material. Furthermore, the sample neutralised with high pressure and temperature registered the lowest $\mathrm{pH}$ values, even with the same acid consumption as for the non-neutralised samples. This is due to the lower $\mathrm{pH}$ of the sample after neutralisation with high pressure and 
Postprint of R.M. Rivera, G. Ounoughene, C.R. Borra, K. Binnemans, T. Van Gerven (2017). Neutralisation of bauxite residue by carbon dioxide prior to acidic leaching for metal recovery. Minerals Engineering 112, 92-102.

temperature. As it was already described in the previous section, during the neutralisation step, high $\mathrm{CO}_{2}$ concentration enhances the reduction of the sample alkalinity as a consequence of sodalite decomposition. Figure 10 reports the $\mathrm{pH}$ values of the sample with and without neutralisation before acidic leaching.

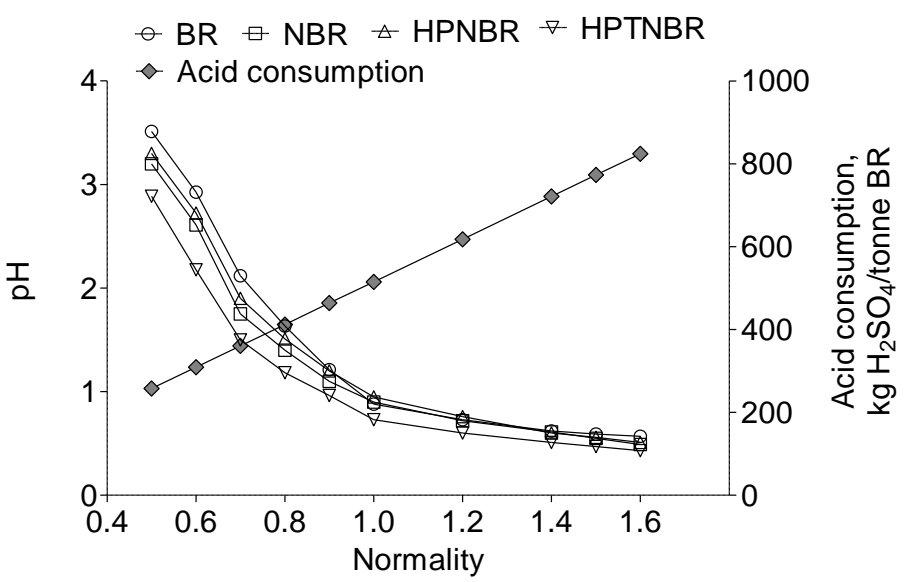

Figure 9: Effect of acid concentration $\left(\mathrm{H}_{2} \mathrm{SO}_{4}\right)$ on the $\mathrm{pH}$ in the non-neutralised and neutralised bauxite residue sample, and acid consumption $\left(T: 25^{\circ} \mathrm{C}, L / S: 10, t: 24 \mathrm{~h}\right)$. BR: non-neutralised bauxite residue, NBR: neutralised bauxite residue at ambient conditions ( $\left.q_{\mathrm{CO} 2}: 0.25 \mathrm{~L} / \mathrm{min}, T: 25^{\circ} \mathrm{C}, L / S: 5\right)$, HPNBR: high-pressure neutralised bauxite residue $\left(P_{\mathrm{CO} 2}: 30\right.$ bar $\left., T: 25^{\circ} \mathrm{C}, L / S: 5\right)$, HPTNBR: high-pressure and high-temperature neutralised bauxite residue $\left(P_{\mathrm{CO} 2}: 30\right.$ bar, $\left.T: 150^{\circ} \mathrm{C}, L / S: 5\right)$.

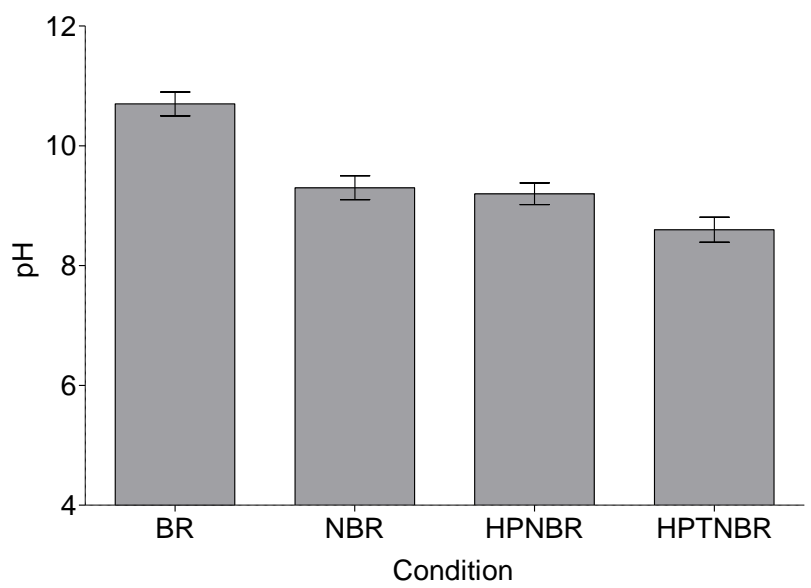

Figure 10: Initial $\mathrm{pH}$ of the non-neutralised bauxite residue and the resulting $\mathrm{pH}$ of the bauxite residue after neutralisation. BR: non-neutralised bauxite residue, NBR: neutralised bauxite residue at ambient conditions $\left(q_{\mathrm{CO} 2}\right.$ : $\left.0.25 \mathrm{~L} / \mathrm{min}, T: 25^{\circ} \mathrm{C}, L / S: 5\right)$, HPNBR: high-pressure neutralised bauxite residue $\left(P_{\mathrm{CO} 2}: 30\right.$ bar, $\left.T: 25^{\circ} \mathrm{C}, L / S: 5\right)$, HPTNBR: high-pressure and high-temperature neutralised bauxite residue $\left(P_{\mathrm{CO} 2}: 30 \mathrm{bar}, T: 150^{\circ} \mathrm{C}, L / S: 5\right)$.

The effect of acid concentration on the leaching of $\mathrm{Al}, \mathrm{Fe}$ and $\mathrm{Ti}$ is shown in Figure 11. Neutralisation at ambient conditions did not result in an improvement of the extraction efficiencies. Indeed, the major 
Postprint of R.M. Rivera, G. Ounoughene, C.R. Borra, K. Binnemans, T. Van Gerven (2017). Neutralisation of bauxite residue by carbon dioxide prior to acidic leaching for metal recovery. Minerals Engineering 112, 92-102.
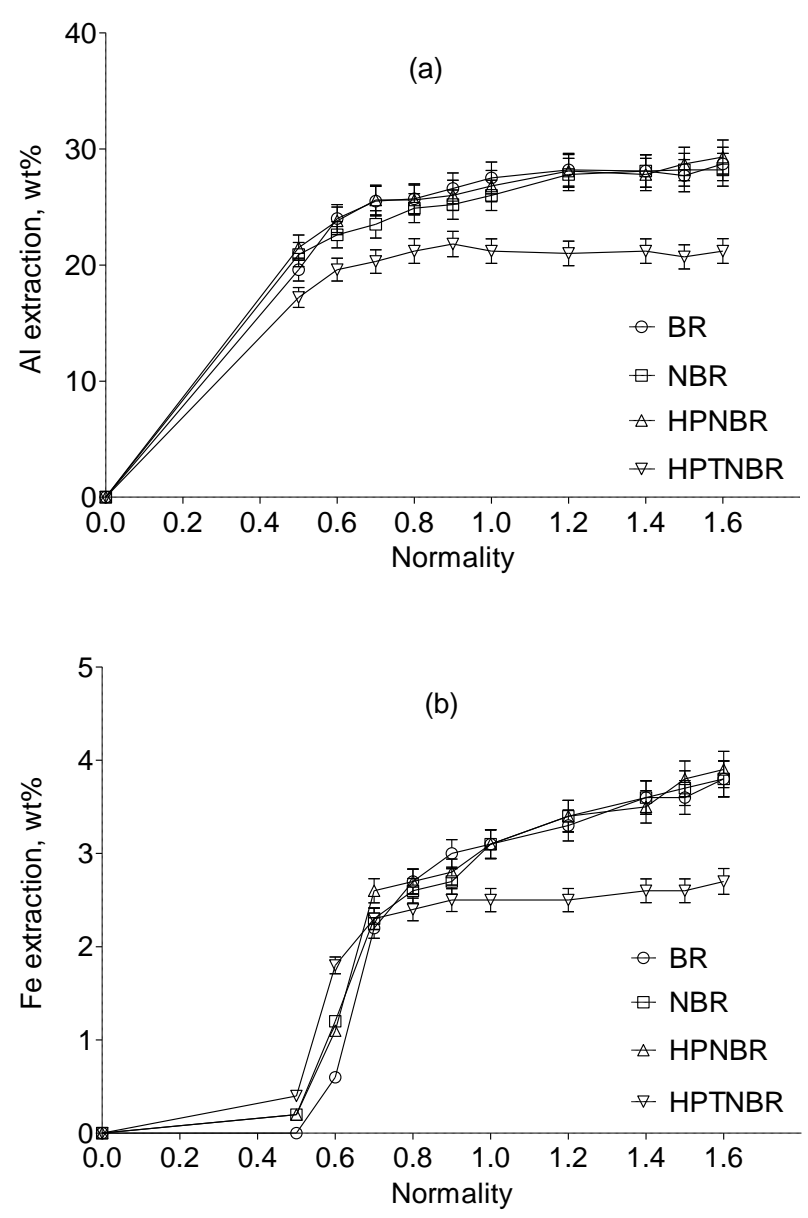

metal recoveries from the neutralised sample with high calcite and cancrinite concentration, i.e. samples neutralised with high $\mathrm{CO}_{2}$ partial pressure, were the lowest with higher acid consumption compared to the non-neutralised sample. This is due to the lack of acid available for leaching, caused by the transformation of calcite into bassanite and the partial decomposition of silicate compounds. As it is shown in Figure 12, a further increase in the extraction of $\mathrm{Al}, \mathrm{Fe}$ or Ti from the highly neutralised sample is limited by $50 \mathrm{wt} \%$ of Si dissolution, even upon further increasing the acid concentration. An increase in silica dissolution leads to a larger supersaturation of silicon, which is considered as the driving force for polymerisation, i.e. gel formation (Hamouda and Amiri, 2014; Tobler et al., 2009). Polymerisation of silica represents a common problem during leaching of silicate minerals (Abkhoshk et al., 2014; Shi et al., 2016; Zhang et al., 2016), which may be promoted by low pH values and high temperatures (Voßenkaul et al., 2016), resulting in problems of solid-liquid separation that increase the required acid consumption and affect the selective recovery of metals. 
Postprint of R.M. Rivera, G. Ounoughene, C.R. Borra, K. Binnemans, T. Van Gerven (2017). Neutralisation of bauxite residue by carbon dioxide prior to acidic leaching for metal recovery. Minerals Engineering 112, 92-102.

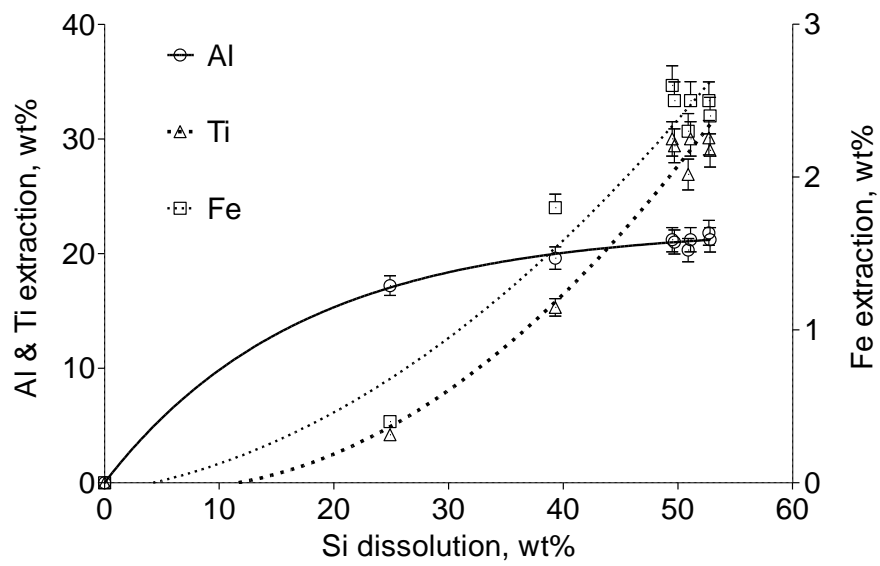

Figure 12: Extraction behaviour of $\mathrm{Al}, \mathrm{Ti}$ and $\mathrm{Fe}$ as function of $\mathrm{Si}$ dissolution after acidic leaching of bauxite residue sample neutralised at $150{ }^{\circ} \mathrm{C}$ and $P_{\mathrm{CO} 2}: 30 \mathrm{bar}\left(\mathrm{H}_{2} \mathrm{SO}_{4}, L / S: 10, T: 25^{\circ} \mathrm{C}, t: 24 \mathrm{~h}\right)$.

Figure 11: Effect of acid concentration on the extraction of (a) $\mathrm{Al}$, (b) $\mathrm{Fe}$ and (c) $\mathrm{Ti}\left(\mathrm{H}_{2} \mathrm{SO}_{4}, L / S: 10, T: 25^{\circ} \mathrm{C}, t\right.$ : 24 h). BR: non-neutralised bauxite residue, NBR: neutralised bauxite residue at ambient conditions ( $q_{\mathrm{CO} 2}: 0.25$ $\left.\mathrm{L} / \mathrm{min}, T: 25^{\circ} \mathrm{C}, L / S: 5\right)$, HPNBR: high-pressure neutralised bauxite residue $\left(P_{\mathrm{CO} 2}: 30\right.$ bar, $\left.T: 25^{\circ} \mathrm{C}, L / S: 5\right)$,

HPTNBR: high-pressure and high-temperature neutralised bauxite residue $\left(P_{\mathrm{CO} 2}: 30\right.$ bar , $\left.T: 150^{\circ} \mathrm{C}, L / S: 5\right)$.

Figure 13 describes the XRD pattern of non-neutralised and neutralised bauxite residue samples after acidic leaching. The most notorious effect of silica gel polymerisation is observed in the large decrease of $\mathrm{Al}$ dissolution upon gibbsite precipitation. Cancrinite was not identified after leaching, presumably because it is totally decomposed by sulfuric acid, although some sodium alumino silicates compounds

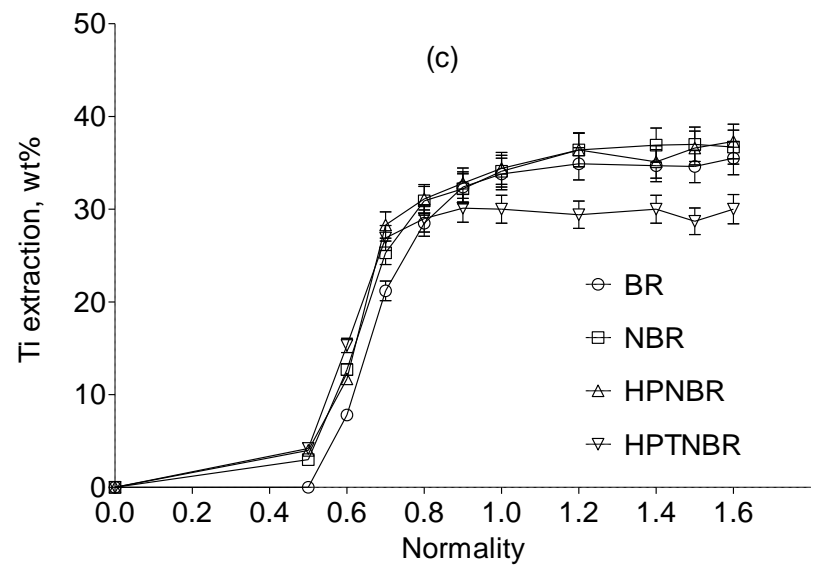
were recognised on both diffractograms. 
Postprint of R.M. Rivera, G. Ounoughene, C.R. Borra, K. Binnemans, T. Van Gerven (2017). Neutralisation of bauxite residue by carbon dioxide prior to acidic leaching for metal recovery. Minerals Engineering 112, 92-102.

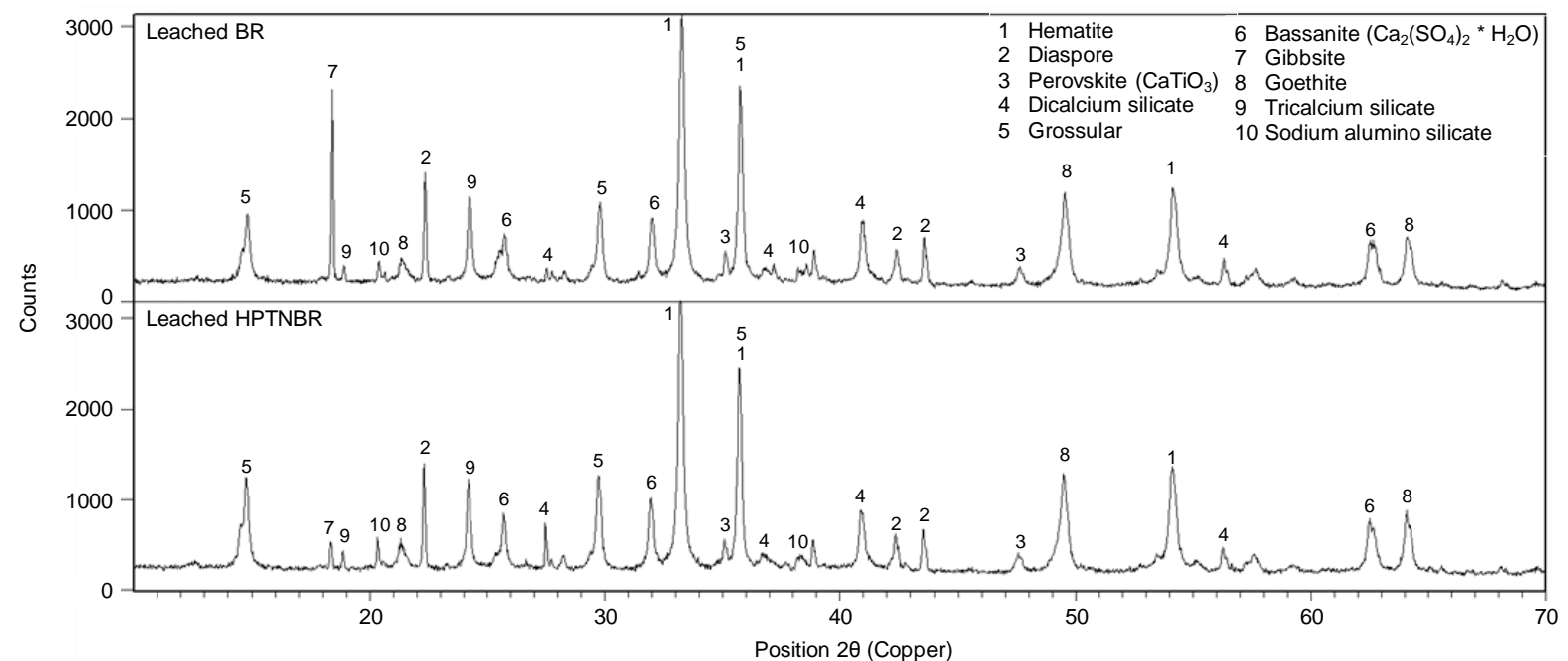

Figure 13: XRD pattern of non-neutralised and neutralised bauxite residue sample after acidic leaching (1.6 N $\mathrm{H}_{2} \mathrm{SO}_{4}$ ). BR: non-neutralised bauxite residue, HPTNBR: high-pressure and high-temperature neutralised bauxite residue $\left(P_{\mathrm{CO} 2}: 30 \mathrm{bar}, T: 150{ }^{\circ} \mathrm{C}, L / S: 5\right)$.

Figure 14 shows the effect of acid concentrations on the leaching of selected REEs. Extraction of Sc, dissolution of $\mathrm{Sc}$ and $\mathrm{Y}$ increased with a decrease in $\mathrm{pH}$ and it reached a maximum when the acid concentration was $0.7 \mathrm{~N}$. The lowest recoveries of Sc and La were achieved in the sample neutralised at high pressure and temperature. The leaching of $\mathrm{Y}$ and $\mathrm{Nd}$ was not affected by $\mathrm{CO}_{2}$ neutralisation, due to their smaller ionic radii compared to Sc and La. However, the extraction of $\mathrm{La}$ and $\mathrm{Nd}$ could be enhanced by increasing the acid concentration.

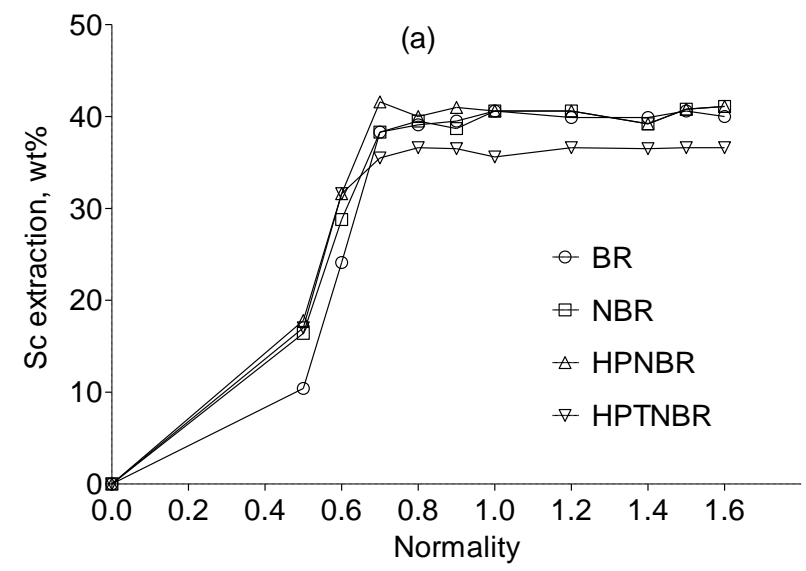


Postprint of R.M. Rivera, G. Ounoughene, C.R. Borra, K. Binnemans, T. Van Gerven (2017). Neutralisation of bauxite residue by carbon dioxide prior to acidic leaching for metal recovery. Minerals Engineering 112, 92-102.

378
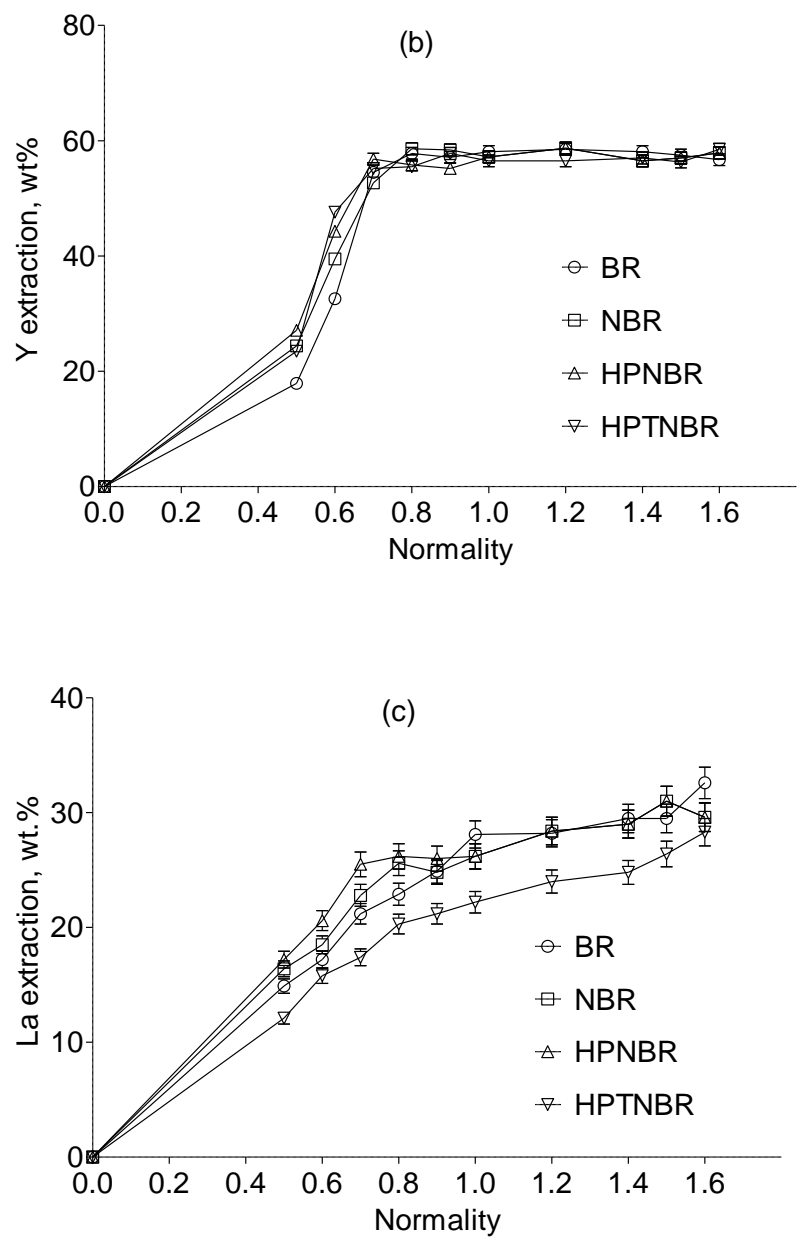

379

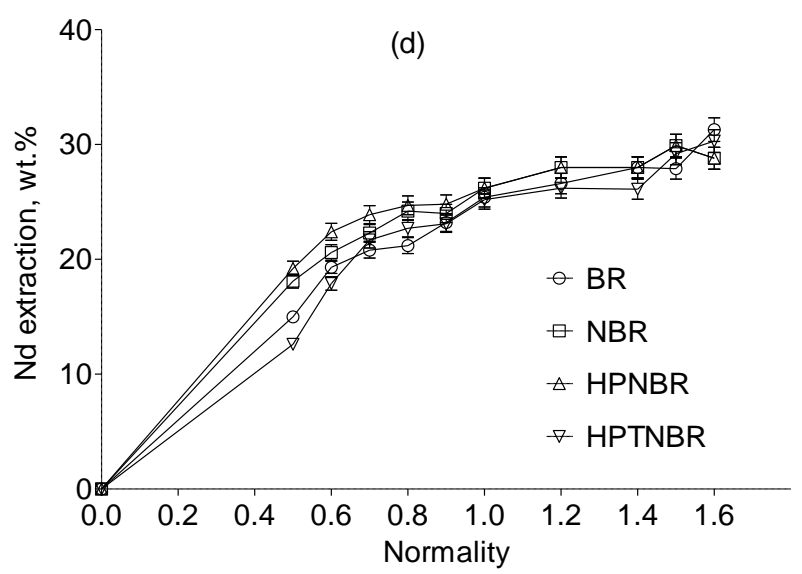

Figure 14: Effect of acid concentration on extraction of selected REEs $\left(\mathrm{H}_{2} \mathrm{SO}_{4}, L / S: 10, T: 25^{\circ} \mathrm{C}, t: 24 \mathrm{~h}\right)$. BR: non-neutralised bauxite residue, NBR: neutralised bauxite residue at ambient conditions $\left(q_{\mathrm{CO} 2}: 0.25 \mathrm{~L} / \mathrm{min}\right.$, $\left.T: 25^{\circ} \mathrm{C}, L / S: 5\right)$, HPNBR: high-pressure neutralised bauxite residue $\left(P_{\mathrm{CO} 2}: 30\right.$ bar, $\left.T: 25^{\circ} \mathrm{C}, L / S: 5\right)$, HPTNBR: high-pressure and high-temperature neutralised bauxite residue $\left(P_{\mathrm{CO} 2}: 30\right.$ bar, $\left.T: 150^{\circ} \mathrm{C}, L / S: 5\right)$. 
Postprint of R.M. Rivera, G. Ounoughene, C.R. Borra, K. Binnemans, T. Van Gerven (2017). Neutralisation of bauxite residue by carbon dioxide prior to acidic leaching for metal recovery. Minerals Engineering 112, 92-102.

386

387

388

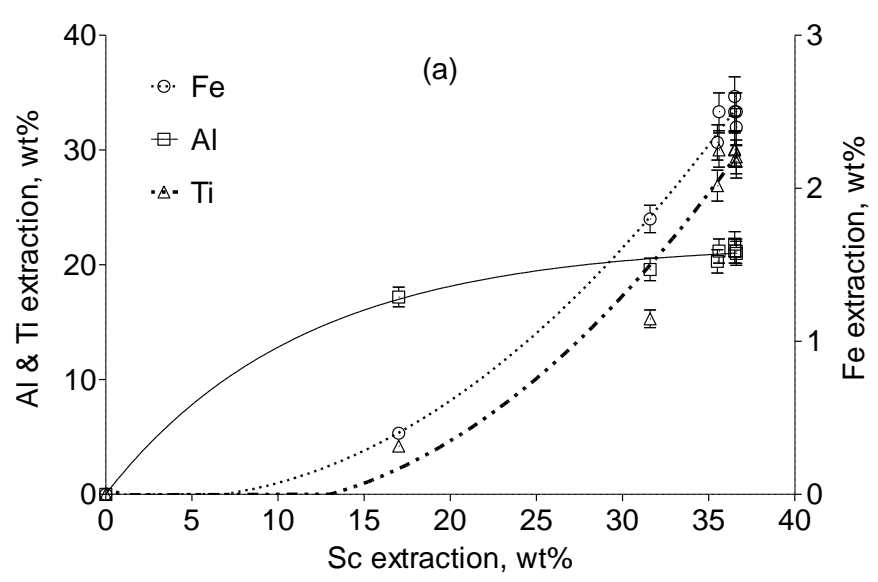

399

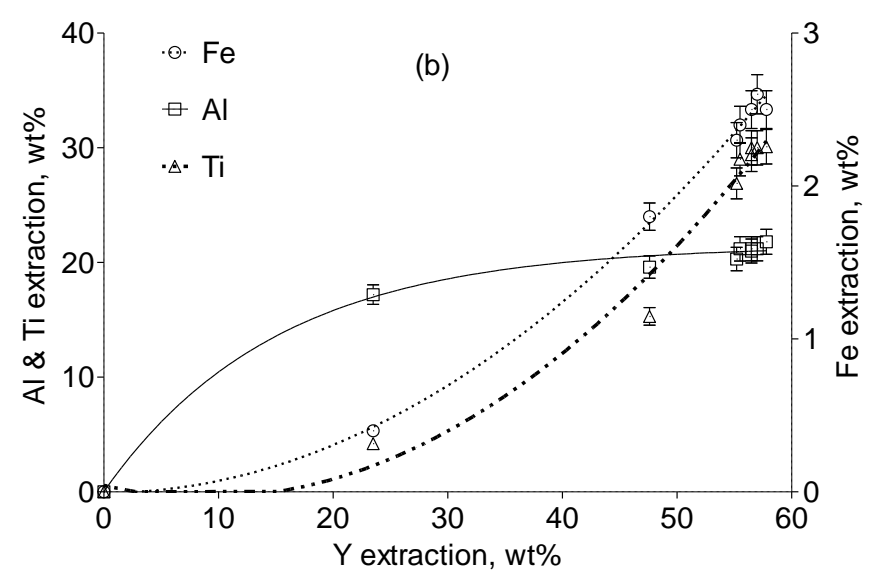

Figure 15 describes the extraction behaviour of Sc and $\mathrm{Y}$ from the highly neutralised sample as function of Al, Fe and Ti dissolution. Although Y recovery was not affected by the neutralisation (Figure 14), the extraction of both Sc and Y is limited by the dissolution of major metals. Up to $40 \mathrm{wt} \%$ of Sc and $60 \mathrm{wt} \%$ of Y is leached with negligible amount of Fe dissolved. Urbain and Sarkar (1927) were the first to report on the chemical association between $\mathrm{Sc}$ and Fe, and recently Borra et al. reported that up to $50 \%$ of Sc can be extracted from bauxite residue without bringing a significant dissolution of Fe into the solution (Borra et al., 2015b), which is confirmed by our results. A similar association trend as between $\mathrm{Sc} / \mathrm{Y}$ and $\mathrm{Fe}$ seems to exist between $\mathrm{Sc} / \mathrm{Y}$ and $\mathrm{Ti}$, although much higher amounts of $\mathrm{Ti}$ (30 wt\%) are dissolved at high levels of Sc and Y leaching. A different relation exists with Al: above 15 wt\% of Al dissolved, Sc and $\mathrm{Y}$ leaching are independent of $\mathrm{Al}$ dissolution. No chemical associations of Sc and Y with major elements other than Fe have been reported so far in literature. In the association with Fe and Ti dissolution, the extent of Y leaching is 1.5 times higher than that of Sc leaching. 
Postprint of R.M. Rivera, G. Ounoughene, C.R. Borra, K. Binnemans, T. Van Gerven (2017). Neutralisation of bauxite residue by carbon dioxide prior to acidic leaching for metal recovery. Minerals Engineering 112, 92-102.

400

401

402

403

404

405

406

407

408

409

410

411
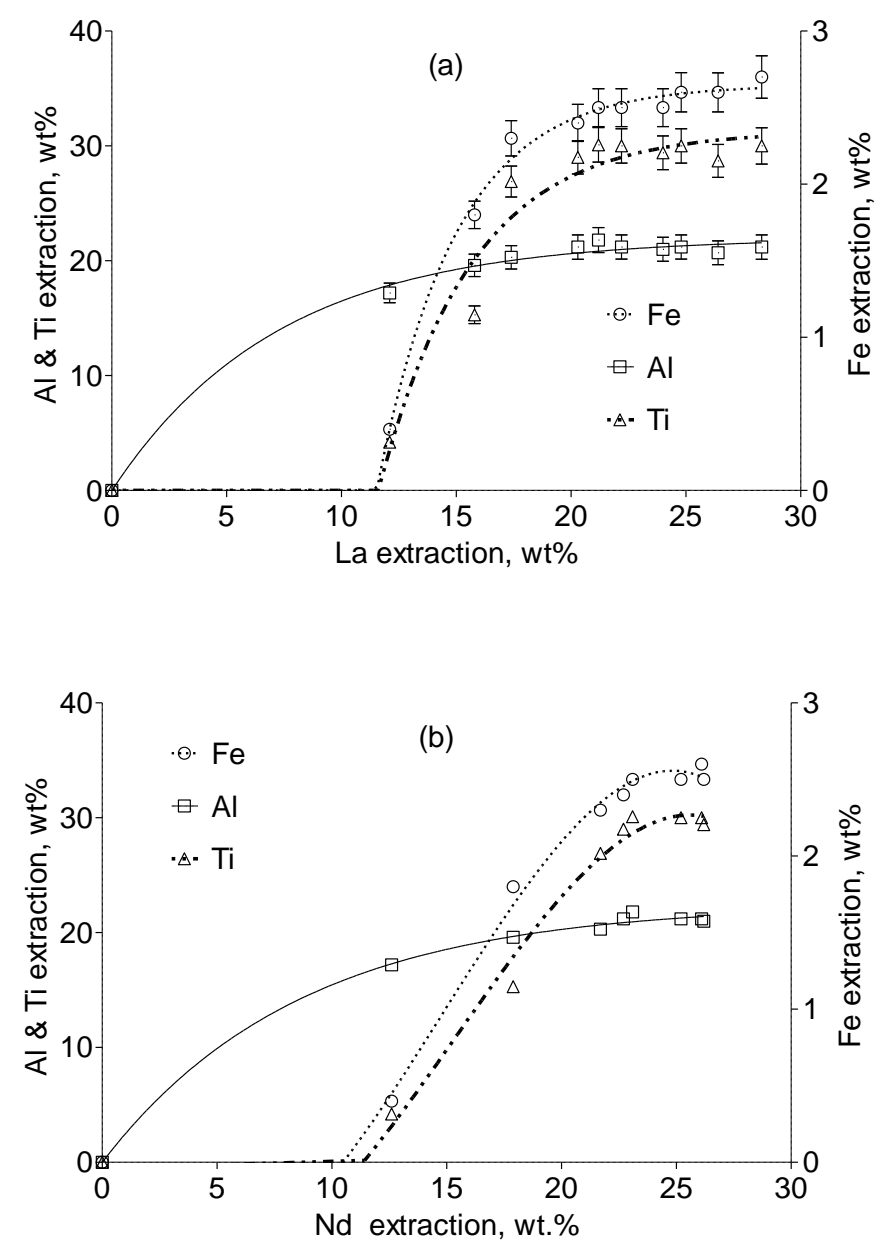

412

413

Figure 15: Extraction behaviour of (a) Sc and (b) $\mathrm{Y}$ as function of $\mathrm{Al}, \mathrm{Ti}$ and $\mathrm{Fe}$ dissolution after acidic leaching of the bauxite residue sample neutralised at $150{ }^{\circ} \mathrm{C}$ and $P_{\mathrm{CO} 2}: 30 \mathrm{bar}\left(\mathrm{H}_{2} \mathrm{SO}_{4}, L / S: 10, T: 25^{\circ} \mathrm{C}, t: 24 \mathrm{~h}\right)$.

The extraction behaviour of La and $\mathrm{Nd}$ from the highly neutralised sample is shown in Figure 16 as function of $\mathrm{Al}, \mathrm{Fe}$ and $\mathrm{Ti}$ dissolution. The correlation between the extraction of $\mathrm{La}$ or $\mathrm{Nd}$ and the dissolution of the major elements is less clear. Again, above a certain threshold of La or $\mathrm{Nd}$ dissolution (between 0 and $12 \mathrm{wt} \%$ in our results), no relation between La or $\mathrm{Nd}$ leaching exists with $\mathrm{Al}$ dissolution. A similar behaviour can be even suggested for $\mathrm{Fe}$ and $\mathrm{Ti}$, where $\mathrm{La}$ and $\mathrm{Nd}$ leaching is independent from $\mathrm{Fe}$ and Ti dissolution from ca. 20 wt \% extraction of La or Nd. However, the leaching of La and $\mathrm{Nd}$ is determined by the amount of free $\mathrm{H}^{+}$ions in solution, which are consumed during the dissolution of major elements and during the decomposition of silicate compounds (Abhilash et al., 2014).

Figure 16: Extraction behaviour of (a) $\mathrm{La}$ and (b) $\mathrm{Nd}$ as function of $\mathrm{Al}$, $\mathrm{Ti}$ and $\mathrm{Fe}$ dissolution after acidic leaching of the bauxite residue sample neutralised at $150{ }^{\circ} \mathrm{C}$ and $P_{\mathrm{CO} 2}: 30 \mathrm{bar}\left(\mathrm{H}_{2} \mathrm{SO}_{4}, L / S: 10, T: 25^{\circ} \mathrm{C}, t: 24 \mathrm{~h}\right)$. 
Postprint of R.M. Rivera, G. Ounoughene, C.R. Borra, K. Binnemans, T. Van Gerven (2017). Neutralisation of bauxite residue by carbon dioxide prior to acidic leaching for metal recovery. Minerals Engineering 112, 92-102.

\section{Conclusions}

417 The two-step processing of bauxite residue via neutralisation and subsequent leaching establishes the

418 effect of $\mathrm{CO}_{2}$ gas as neutralisation reagent on the extraction efficiencies of metal recovery via acidic 419 leaching. The minimum $\mathrm{pH}$ attained after neutralisation in our bauxite residue with $\mathrm{CO}_{2}$ was 8.6. Further $\mathrm{pH}$ decrease is limited, because of the chemical association of sodium to the sparsely soluble silicate compounds. The increase of temperature leads to a strong decomposition of silicate minerals, which allows the reduction of alkalinity upon carbonation of sodium and calcium. However, the intensification of neutralisation at elevated temperatures and high $\mathrm{CO}_{2}$ partial pressures leads to the formation of calcite and cancrinite, the latter upon decomposition of sodalite. Silicate compounds became more stable in the neutralised samples rather than in the non-neutralised bauxite residue, due to the decrease of $\mathrm{SiO}_{2}$ solubility with a high sodium dissolution. The extraction of $\mathrm{Al}, \mathrm{Fe}$ and $\mathrm{Ti}$ was reduced due to the insufficient availability of acid caused by acid consumption for the chemical transformation of calcite into bassanite and the polymerisation of amorphous silica. The recovery of Sc from highly neutralised bauxite residue is lower compared to that from the less neutralised, or even non-neutralised, one due to its chemical association with major elements. The recovery of $\mathrm{La}$ and $\mathrm{Nd}$ is determined by the acid concentration upon a limit recovery of major elements and high silica polymerisation.

\section{Acknowledgements}

The research leading to these results has received funding from the European Community's Horizon 2020 Programme (H2020/2014-2019) under Grant Agreement No. 636876 (MSCA- ETN REDMUD). This publication reflects only the authors' view, exempting the Community from any liability. Project website: http://www.etn.redmud.org. The authors thank Aluminium of Greece for providing the bauxite residue sample. 
Postprint of R.M. Rivera, G. Ounoughene, C.R. Borra, K. Binnemans, T. Van Gerven (2017). Neutralisation of bauxite residue by carbon dioxide prior to acidic leaching for metal recovery. Minerals Engineering 112, 92-102.

\section{References}

Abhilash, S., Kumar, M., Dhar, B., 2014. Extraction of lanthanum and cerium from Indian red mud. Int. J. Miner. Process. 127, 70-73. doi:10.1016/j.minpro.2013.12.009

Abkhoshk, E., Jorjani, E., Al-Harahsheh, M.S., Rashchi, F., Naazeri, M., 2014. Review of the hydrometallurgical processing of non-sulfide zinc ores. Hydrometallurgy 149, 153-167. doi:10.1016/j.hydromet.2014.08.001

Agatzini-Leonardou, S., Oustadakis, P., Tsakiridis, P.E., Markopoulos, C., 2008. Titanium leaching from red mud by diluted sulfuric acid at atmospheric pressure. J. Hazard. Mater. 157, 579-586. doi:10.1016/j.jhazmat.2008.01.054

Atasoy, A., 2005. An investigation on characterization and thermal analysis of the Aughinish red mud. J. Therm. Anal. Calorim. 81, 357-361. doi:10.1007/s10973-005-0792-5

Barnes, M.C., Addai-Mensah, J., Gerson, A.R., 1999. The solubility of sodalite and cancrinite in synthetic spent Bayer liquor. Colloids Surfaces A Physicochem. Eng. Asp. 157, 101-116. doi:10.1016/S0927-7757(99)00058-8

Binnemans, K., Jones, P.T., Blanpain, B., Van Gerven, T., Pontikes, Y., 2015. Towards zero-waste valorisation of rare-earth-containing industrial process residues: a critical review. J. Clean. Prod. 99, 17-38. doi:10.1016/j.jclepro.2015.02.089

Bonenfant, D., Kharoune, L., Hausler, R., Niquette, P., 2008. $\mathrm{CO}_{2}$ Sequestration by aqueous red mud carbonation at ambient pressure and temperature. Ind. Eng. Chem. Res. 47, 7610-7616.

Borra, C.R., Blanpain, B., Pontikes, Y., Binnemans, K., Van Gerven, T., 2016. Recovery of rare earths and other valuable metals from bauxite residue (red mud): a review. J. Sustain. Met. Submitted. doi:10.1007/s40831-016-0068-2

Borra, C.R., Mermans, J., Blanpain, B., Pontikes, Y., Van Gerven, T., 2015a. Selective leaching of rare earths from bauxite residue after sulphation roasting, in: Bauxite Residue Valorization and Best Practices, Leuven, (Belgium), 5-7 Ocotber 2015, Pp. 301-307.

Borra, C.R., Pontikes, Y., Binnemans, K., Van Gerven, T., 2015b. Leaching of rare earths from bauxite residue (red mud). Miner. Eng. 76, 20-27. doi:10.1016/j.mineng.2015.01.005

Cooling, D.J., Hay, P.S., Guilfoyle, L., 2002. Carbonation of bauxite residue, in: 6th International Alumina Quality Workshop. pp. 185-190.

Evans, K., 2016. Successes and Challenges in the Management and Use of Bauxite Residue. J. Sustain. Met. 2, 316-331. doi:10.1007/s40831-016-0060-x

Gräfe, M., Power, G., Klauber, C., 2011. Bauxite residue issues: III. Alkalinity and associated chemistry. Hydrometallurgy 108, 60-79. doi:10.1016/j.hydromet.2011.02.004

Hamouda, A.A., Amiri, H.A.A., 2014. Factors affecting alkaline sodium silicate gelation for in-depth reservoir profile modification. Energies 7, 568-590. doi:10.3390/en7020568

Han, Y.-S., Ji, S., Lee, P.-K., Oh, C., 2017. Bauxite residue neutralization with simultaneous mineral carbonation using atmospheric $\mathrm{CO}_{2}$. J. Hazard. Mater. 326, 87-93. doi:10.1016/j.jhazmat.2016.12.020

Hanahan, C., McConchie, D., Pohl, J., Creelman, R., Clark, M., Stocksiek, C., 2004. Chemistry of Seawater Neutralization of Bauxite Refinery Residues (Red Mud). Environ. Eng. Sci. 21, 125138. doi:10.1089/109287504773087309

Khaitan, S., Dzombak, D.A., Lowry, G. V., 2009a. Chemistry of the acid neutralization capacity of bauxite residue. Environ. Eng. Sci. 26, 873-881. 
Postprint of R.M. Rivera, G. Ounoughene, C.R. Borra, K. Binnemans, T. Van Gerven (2017). Neutralisation of bauxite residue by carbon dioxide prior to acidic leaching for metal recovery. Minerals Engineering 112, 92-102.

Khaitan, S., Dzombak, D. a., Lowry, G. V., 2009b. Mechanisms of neutralization of bauxite residue by carbon dioxide. J. Environ. Eng. 135, 433-438. doi:10.1061/(ASCE)EE.1943-7870.0000010

Kirwan, L.J., Hartshorn, A., McMonagle, J.B., Fleming, L., Funnell, D., 2013. Chemistry of bauxite residue neutralisation and aspects to implementation. Int. J. Miner. Process. 119, 40-50. doi:10.1016/j.minpro.2013.01.001

Kloprogge, J.T., Ruan, H.D., Frost, R.L., 2002. Thermal decomposition of bauxite minerals : Infrared emission spectroscopy of gibbsite, boehmite and diaspore. J. Mater. Sci. 37, 1121-1129.

Lutpi, N.A., Zhu, J., 2010. Carbonation of bauxite residue: a solution for carbon dioxide capture in alumina industry, in: ICSTIE 2010.

Ochsenkühn-Petropulu, M., Hatzilyberis, K.S., Mendrinos, L.N., Salmas, C.E., 2002. Pilot-Plant investigation of the leaching process for the recovery of scandium from red mud. Ind. Eng. Chem. Res. 41, 5794-5801. doi:10.1021/ie011047b

Ochsenkühn-Petropulu, M., Lyberopulu, T., Ochsenkühn, K.M., Parissakis, G., 1996. Recovery of lanthanides and yttrium from red mud by selective leaching. Anal. Chim. Acta 319, 249-254. doi:10.1016/0003-2670(95)00486-6

Rai, S., Wasewar, K.L., Lataye, D.H., Mukhopadhyay, J., Yoo, C.K., 2013. Feasibility of red mud neutralization with seawater using Taguchi's methodology. Int. J. Environ. Sci. Technol. 10, 305314. doi:10.1007/s13762-012-0118-7

Rai, S., Wasewar, K.L., Mukhopadhyay, J., Yoo, C.K., Uslu, H., 2012. Neutralization and utilization of red mud for its better waste management. Arch. Environ. Sci. 6, 13-33.

Reddy, S.K., Balasubramanian, S., 2014. Carbonic acid: molecule, crystal and aqueous solution. Chem. Commun. 50, 503-514. doi:10.1039/C3CC45174G

Rizov, B., 2012. Phase transformations from goethite to hematite and thermal decomposition in various nickeliferous laterite ores. J. Univ. Chem. Technol. Metall. 47, 207-210.

Sahu, R.C., Patel, R.K., Ray, B.C., 2010. Neutralization of red mud using $\mathrm{CO}_{2}$ sequestration cycle. J. Hazard. Mater. 179, 28-34. doi:10.1016/j.jhazmat.2010.02.052

Santos, R.M., Bouwel, J. Van, Vandevelde, E., Mertens, G., Elsen, J., Gerven, T. Van, 2013. Accelerated mineral carbonation of stainless steel slags for $\mathrm{CO}_{2}$ storage and waste valorization: Effect of process parameters on geochemical properties. Int. J. Greenh. Gas Control 17, 32-45. doi:10.1016/j.ijggc.2013.04.004

Shi, L., Ruan, S., Li, J., Gerson, A.R., 2016. Desilication of low alumina to caustic liquor seeded with sodalite or cancrinite. Hydrometallurgy. doi:10.1016/j.hydromet.2016.06.023

Tanutrov, I.N., Sviridova, M.N., Savenya, A.N., 2013. A new technology for coprocessing man-made wastes. J. Non-Ferrous Met. 54, 136-142. doi:10.3103/S1067821213020132

Tobler, D.J., Shaw, S., Benning, L.G., 2009. Quantification of initial steps of nucleation and growth of silica nanoparticles: An in-situ SAXS and DLS study. Geochim. Cosmochim. Acta 73, 53775393. doi:10.1016/j.gca.2009.06.002

Voßenkaul, D., Birich, A., Müller, N., Stoltz, N., Friedrich, B., 2016. Hydrometallurgical processing of eudialyte bearing concentrates to recover rare earth elements via low-temperature dry digestion to prevent the silica gel formation. J. Sustain. Metall. doi:10.1007/s40831-016-0084-2

Whittington, B.I., Cardile, C.M., 1996. The chemistry of tricalcium aluminate hexahydrate relating to the Bayer industry. Int. J. Miner. Process. 48, 21-38. doi:10.1016/S0301-7516(96)00011-7

Yadav, V.S., Prasad, M., Khan, J., Amritphale, S.S., Singh, M., Raju, C.B., 2010. Sequestration of carbon dioxide $\left(\mathrm{CO}_{2}\right)$ using red mud. J. Hazard. Mater. 176, 1044-1050. 
Postprint of R.M. Rivera, G. Ounoughene, C.R. Borra, K. Binnemans, T. Van Gerven (2017). Neutralisation of bauxite residue by carbon dioxide prior to acidic leaching for metal recovery. Minerals Engineering 112, 92-102. doi:10.1016/j.jhazmat.2009.11.146

Zhang, Y., Hua, Y., Gao, X., Xu, C., Li, J., Li, Y., Zhang, Q., Xiong, L., Su, Z., Wang, M., Ru, J., 2016. Recovery of zinc from a low-grade zinc oxide ore with high silicon by sulfuric acid curing and water leaching. Hydrometallurgy 166, 16-21. doi:10.1016/j.hydromet.2016.08.010

Zheng, K., Gerson, A.R., Addai-Mensah, J., Smart, R.S.C., 1997. The influence of sodium carbonate on sodium aluminosilicate crystallisation and solubility in sodium aluminate solutions. J. Cryst. Growth 171, 197-208. doi:10.1016/S0022-0248(96)00480-0

Zheng, K., Smart, R.S.C., Addai-Mensah, J., Gerson, A., 1998. Solubility of Sodium Aluminosilicates in Synthetic Bayer Liquor. J. Chem. Eng. Data 43, 312-317. doi:10.1021/je970187i 
Postprint of R.M. Rivera, G. Ounoughene, C.R. Borra, K. Binnemans, T. Van Gerven (2017). Neutralisation of bauxite residue by carbon dioxide prior to acidic leaching for metal recovery. Minerals Engineering 112, 92-102.

7. Supplementary material

539 Table S1: Full mineralogical composition analysis (wt\%) of the bauxite residue samples.

\begin{tabular}{|c|c|c|c|c|c|}
\hline Phase & Chemical formula & $\mathrm{BR}$ & NBR & $\begin{array}{c}\text { HP } \\
\text { NBR } \\
\end{array}$ & $\begin{array}{l}\text { HPT } \\
\text { NBR }\end{array}$ \\
\hline Hematite & $\mathrm{Fe}_{2} \mathrm{O}_{3}$ & 34 & 34 & 37 & 37 \\
\hline Dicalcium-silicate $\left(\mathrm{C}_{2} \mathrm{~S}\right)$ & $\mathrm{Ca}_{2} \mathrm{SiO}_{4}$ & 11 & 8 & 2 & 3 \\
\hline Gibbsite & $\mathrm{Al}(\mathrm{OH})_{3}$ & 8 & 9 & 5 & 3 \\
\hline Hydrogrossular & $\mathrm{Ca}_{3} \mathrm{Al}_{2}\left(\mathrm{SiO}_{4}\right)_{1.53}(\mathrm{OH})_{5.88}$ & 7 & 7 & 9 & 6 \\
\hline Diaspore & $\mathrm{AlO}(\mathrm{OH})$ & 7 & 8 & 6 & 6 \\
\hline Grossular & $\mathrm{Ca}_{3} \mathrm{Al}_{2}\left(\mathrm{SiO}_{4}\right)_{3}$ & 5 & 8 & 10 & 8 \\
\hline Tricalcium-silicate $\left(\mathrm{C}_{3} \mathrm{~S}\right)$ & $\mathrm{Ca}_{3} \mathrm{SiO}_{5}$ & 4 & 4 & 3 & 4 \\
\hline Goethite & $\mathrm{FeO}(\mathrm{OH})$ & 4 & 4 & 5 & 5 \\
\hline Calcite & $\mathrm{CaCO}_{3}$ & 4 & 4 & 5 & 9 \\
\hline Bayerite & $\alpha-\mathrm{Al}(\mathrm{OH})_{3}$ & 4 & 3 & 3 & 3 \\
\hline Sodalite & $\mathrm{Na}_{6}\left(\mathrm{Al}_{6} \mathrm{Si}_{6} \mathrm{O}_{24}\right) \cdot x \mathrm{NaOH} \cdot(8-2 x) \mathrm{H}_{2} \mathrm{O}$ & 3 & 2 & 1 & 1 \\
\hline $\begin{array}{l}\text { Calcium phyllo-dodeca- } \\
\text { alumotetrasilicate }\end{array}$ & $\mathrm{Al}_{12} \mathrm{CaO}_{27} \mathrm{Si}_{4}$ & 2 & 2 & 3 & 2 \\
\hline Rutile & $\mathrm{TiO}_{2}$ & 2 & 1 & 3 & 3 \\
\hline Cancrinite & $\mathrm{Na}_{6} \mathrm{Ca}_{2} \mathrm{Al}_{6} \mathrm{Si}_{6} \mathrm{O}_{24}\left(\mathrm{CO}_{3}\right)_{2} \cdot 2 \mathrm{H}_{2} \mathrm{O}$ & 1 & 1 & 4 & 7 \\
\hline Total & & 95 & 96 & 95 & 96 \\
\hline Unidentified & & 5 & 4 & 5 & 4 \\
\hline
\end{tabular}


Postprint of R.M. Rivera, G. Ounoughene, C.R. Borra, K. Binnemans, T. Van Gerven (2017). Neutralisation of bauxite residue by carbon dioxide prior to acidic leaching for metal recovery. Minerals Engineering 112, 92-102.

Table S2: Normalised mineralogical composition (wt\%) of the bauxite residue samples (cf. Table S1).

\begin{tabular}{|c|c|c|c|c|c|}
\hline Phase & Chemical formula & $\mathrm{BR}$ & NBR & $\begin{array}{c}\text { HP } \\
\text { NBR }\end{array}$ & $\begin{array}{l}\text { HPT } \\
\text { NBR }\end{array}$ \\
\hline Hematite & $\mathrm{Fe}_{2} \mathrm{O}_{3}$ & 36 & 35 & 39 & 39 \\
\hline Dicalcium-silicate $\left(\mathrm{C}_{2} \mathrm{~S}\right)$ & $\mathrm{Ca}_{2} \mathrm{SiO}_{4}$ & 12 & 8 & 3 & 3 \\
\hline Gibbsite & $\mathrm{Al}(\mathrm{OH})_{3}$ & 8 & 9 & 5 & 3 \\
\hline Hydrogrossular & $\mathrm{Ca}_{3} \mathrm{Al}_{2}\left(\mathrm{SiO}_{4}\right)_{1.53}(\mathrm{OH})_{5.88}$ & 7 & 7 & 9 & 6 \\
\hline Diaspore & $\mathrm{AlO}(\mathrm{OH})$ & 7 & 8 & 6 & 6 \\
\hline Grossular & $\mathrm{Ca}_{3} \mathrm{Al}_{2}\left(\mathrm{SiO}_{4}\right)_{3}$ & 5 & 8 & 11 & 9 \\
\hline Tricalcium-silicate $\left(\mathrm{C}_{3} \mathrm{~S}\right)$ & $\mathrm{Ca}_{3} \mathrm{SiO}_{5}$ & 5 & 4 & 3 & 4 \\
\hline Goethite & $\mathrm{FeO}(\mathrm{OH})$ & 5 & 4 & 5 & 5 \\
\hline Calcite & $\mathrm{CaCO}_{3}$ & 4 & 5 & 5 & 9 \\
\hline Bayerite & $\alpha-\mathrm{Al}(\mathrm{OH})_{3}$ & 4 & 3 & 3 & 3 \\
\hline Sodalite & $\mathrm{Na}_{6}\left(\mathrm{Al}_{6} \mathrm{Si}_{6} \mathrm{O}_{24}\right) \cdot x \mathrm{NaOH} \cdot(8-2 \mathrm{x}) \mathrm{H}_{2} \mathrm{O}$ & 3 & 2 & 1 & 1 \\
\hline $\begin{array}{l}\text { Calcium phyllo-dodeca- } \\
\text { alumotetrasilicate }\end{array}$ & $\mathrm{Al}_{12} \mathrm{CaO}_{27} \mathrm{Si}_{4}$ & 2 & 2 & 3 & 2 \\
\hline Rutile & $\mathrm{TiO}_{2}$ & 2 & 2 & 3 & 3 \\
\hline Cancrinite & $\mathrm{Na}_{6} \mathrm{Ca}_{2} \mathrm{Al}_{6} \mathrm{Si}_{6} \mathrm{O}_{24}\left(\mathrm{CO}_{3}\right)_{2} \cdot 2 \mathrm{H}_{2} \mathrm{O}$ & 1 & 1 & 4 & 7 \\
\hline Total & & 100 & 100 & 100 & 100 \\
\hline
\end{tabular}

$\mathrm{BR}=$ non-neutralised bauxite residue, $\mathrm{NBR}=$ neutralised bauxite residue at ambient conditions $\left(q_{\mathrm{CO} 2}: 0.25 \mathrm{~L} / \mathrm{min}, T: 25{ }^{\circ} \mathrm{C}, L / S: 5\right)$, $\mathrm{HP}$ NBR $=$ high-pressure neutralised bauxite residue $\left(P_{\mathrm{CO} 2}: 30\right.$ bar, $\left.T: 25^{\circ} \mathrm{C}, L / S: 5\right)$, HPT NBR = high-pressure and high-temperature neutralised bauxite residue (PCO2: 30 bar, $\left.\mathrm{T}: 150^{\circ} \mathrm{C}, \mathrm{L} / \mathrm{S}: 5\right) \ldots$. 